Kutsenko Dmytro Mykolayovych

Postgraduate student of the Department of management and economic security, Bogdan Khmelnitsky National University of Cherkasy, Cherkasy, Ukraine

Orcid ID: https://orcid.org/0000-0001-6379-2330 lawagens@gmail.com

\title{
ORIENTERS OF STRATEGIC MANAGEMENT OF FINANCIAL AND ECONOMIC SECURITY OF ENTERPRISES: INTERESTS, CHALLENGES, RISKS
}

The article the author's definition of strategic management of financial and economic security is proposed. Specifics of the formation of strategies for the provision of financial and economic security of economic structures are specified. The list of main challenges and risks for the financial and economic security of domestic enterprises is determined. The author's approach to organization of the process of introduction of strategic management of financial and economic security at enterprises is offered. Strategic benchmarks for managing financial and economic security in accordance with business expectations of Ukrainian enterprises are established.

Keywords: management, financial and economic security, strategic management, threats, interests, challenges, risks.

Introduction. The management of financial and economic security of business structures has been a pressing issue for several years now, which is being researched both in the scientific plane and at the applied level in the form of numerous attempts to develop effective mechanisms of security-oriented management taking into account the functional characteristics of economic entities of various types of economic activity. Of particular significance now is the issue of strategic management of financial and economic security. This is due to the fact that enterprises, institutions and organizations accustomed to struggle for their competitiveness, profitability and economic survival in the face of threats to the domestic market; however, this struggle is shaped by a spontaneous, instantaneous response to the danger that has been discovered by means of analyzing and monitoring the state of the market environment and the internal environment of the business structure. Thus, as of mid-2019, the management of financial and economic security is nothing but separate, operational responses to threats and tactical actions to overcome the consequences of their negative impact on the resources and interests of the business entity. However, the effectiveness of the management process could be substantially enhanced by planning security-oriented measures, forecasting threats and risks of the state of financial and economic security of enterprises, etc. In view of this, there is a need to develop strategies for ensuring financial and economic security, which should become a priority task of strategic management of it at the level of participants in market relations.

Literature review. Problems of formation of theoretical and methodical principles of financial and economic security management at both micro and macro level were reflected in the scientific works of domestic scientists. In general, worth attention the publication of such researchers as Furman V.M., who determines the features of economic security management of modern insurance companies as one of the types of financial institutions [1], Zachosova N.V., who offers theoretical and methodological principles of economic security management in the process of management of modern financial institutions [2], and also attempts to show the model of the mechanism for managing the provision of financial and economic security of professional participants in the financial market, taking into account the state influence on this process [3], Zanora V.O., who laying out the theoretical and methodological aspects of organizing the system of economic security of economic entities in the process of managing it [4], as well as specifies the features of management of the enterprise's economic security system on the basis of the project 
approach [5], Herasimenko O.M , who studies the peculiarities of the management of the system of financial and economic security of the manufacturing firm [6], and of many others. The analysis of the materials of these scientific works allowed to conclude that some aspects of strategic management of financial and economic safety of security specialists ignore the problem of safetyoriented management, but some provisions can be traced back to sources [7-17]. At the same time, the volatility of the environment, increasing the number of threats to the economic security of economic structures, the emergence of their new, non-traditional forms and types complicate the process of forecasting and planning of security-oriented management measures, which calls for a comprehensive study of the strategic management of financial and economic security at the micro level, taking into account risks, which are inherent to him, and the expected consequences of his professional implementation for different categories of stakeholders of enterprises.

The purpose of the article. The purpose of the paper is to specify the directives of strategic management of financial and economic security of enterprises, which are determined on the basis of financial and economic interests of economic entities and their stakeholders, the challenges faced by the enterprise in the external and internal environment in the process of their implementation, as well as risks for their financial and economic security. To accomplish this goal, it is necessary to fulfill the following tasks: to determine the list of main challenges and risks for the financial and economic security of domestic enterprises, to propose an author's approach to the definition of strategic management of financial and economic security and to organize the process of introducing strategic management of financial and economic security at enterprises, establish strategic guidelines for managing financial and economic security in line with business expectations of Ukrainian enterprises at the end of the first quarter of 2019.

Results and discussion. The importance of the strategic context in the issues of financial and economic security management has been repeatedly emphasized by researchers in the problems of security science. Thus, O.I. Sudakova, V.V. Popova, M.K. Orlova, suggesting an author's definition of economic security, note that this concept should be defined as "ensuring the realization of strategic interests of the enterprise on the basis of the use of opportunities of the environment with the use of productive interaction with subjects of the environment "[12, c.242]. Researchers also emphasize the importance of following economic and financial interests of the company in managing its financial and economic security in the strategic perspective. In particular, their publication notes that "the efforts of enterprises to ensure their own economic security, especially at the strategic time interval should be directed to ensure the implementation of strategic economic interests of the enterprise by establishing a controlled productive interaction with the actors of the environment" [12, c.245].

The main financial and economic interest of the functioning of most economic entities is the profit. Its expectation and reception is the motive for the start of all types of entrepreneurial activity. Loss-making enterprises are forced to declare themselves bankrupt and leave the market through a liquidation mechanism. The dynamics of the number of economic entities of various types of economic activity, analyzed in retrospect for a sufficiently long period of time, can indicate the general state of economic security of business structures within the national economy (Fig. 1).

According to Fig. 1, there is a tendency to reduce the number of economic entities in Ukraine from 2010 to 2013. This tendency can be explained by the negative consequences of the global financial crisis of 2008-2009, when, every year following its peak in the international financial markets, even those domestic enterprises that had a reserve of financial strength and managed to survive the first wave of its negative consequences, however, were manifested unable to withstand a financial crisis for a long period of time. From 2013 to 2015 there is a tendency to increase the number of business structures - the national economy has adapted to the post-crisis situation and began its recovery, when again, in 2014, it will strike a new crisis, but already local, internal, provoked by the political situation, revolution and the beginning of war conflict. The strength of its influence on the domestic economy was so powerful that the indicators of the number of economic entities by the end of 2017 did not recover to the level of 2010. In fact, the national economy, due to the consequences of two crises - the global financial and local political, "retreated" ten years ago, 
which has become a reason for Ukraine to become one of the backward countries of Europe in terms of economic development.

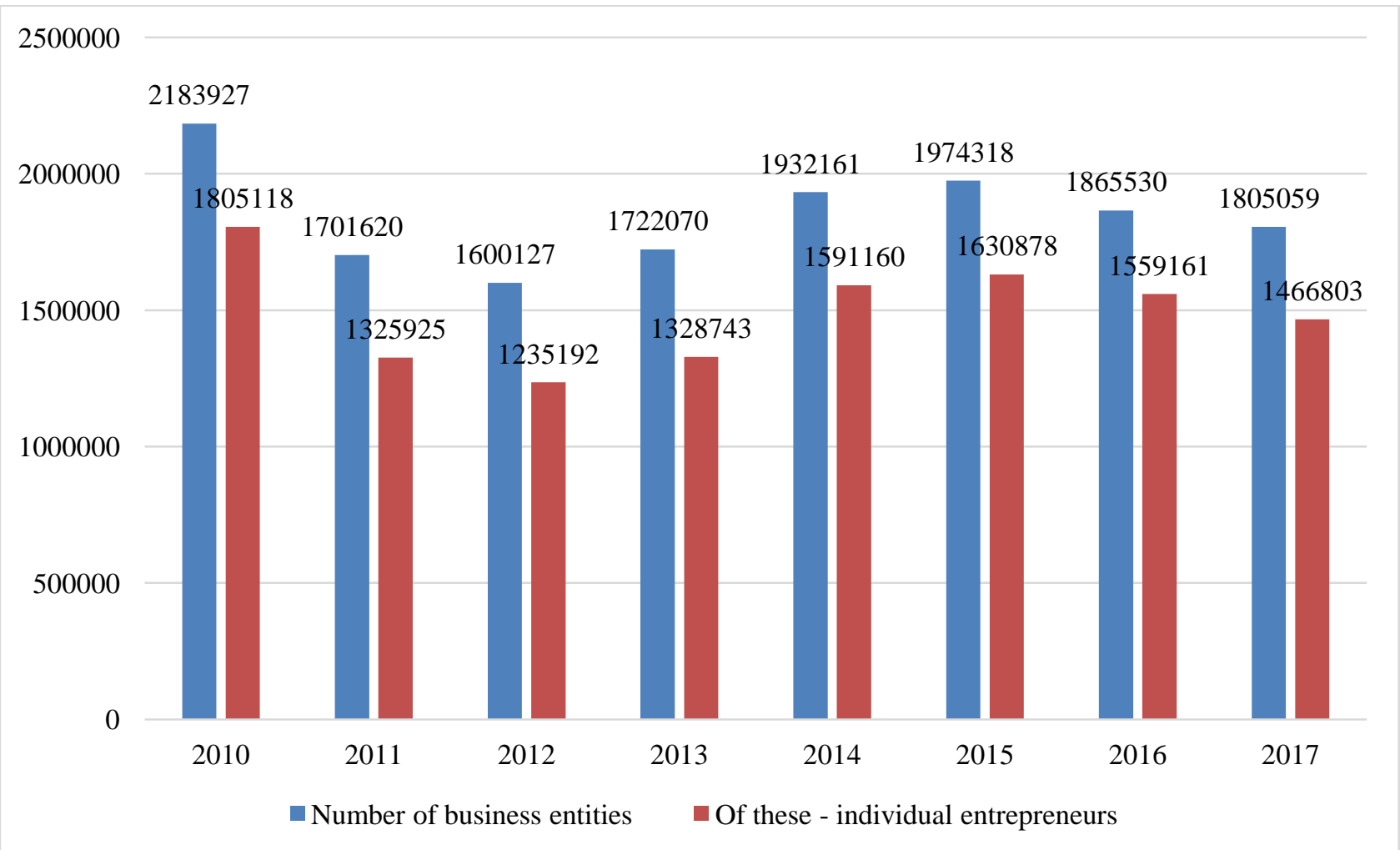

Fig.1. Statistics of the number of economic entities in Ukraine [18]

A characteristic feature of the domestic economy is the high proportion of individualsentrepreneurs in the total number of economic entities. This is evidence of the lack of large, financially powerful business structures in Ukraine, and in the absence of support for small businesses, the economic system may face another crisis and stagnation.

Was it possible to prevent massive bankruptcy of enterprises in the event that their management had a strategic plan to ensure financial and economic security? It is unlikely that the events that took place in those turbulent times have the character of force majeure. However, it can be assumed that the processes of bankruptcy and liquidation of enterprises would not happen so suddenly, and their number would be significantly less, and sanitation procedures more effective, so that top management was prepared for the probability of occurrence of crisis phenomena and intensification of external economic threats and challenges. That is, a strategy for managing financial and economic security could become a competitive advantage, and even a tool to mitigate the impact of the crisis on the results of domestic enterprises.

Let's return to the problem of low profitability of economic structures, which leads in the long-term and medium-term prospects to their unprofitableness. Figure 2 shows the number of unprofitable business entities and their financial results for the period from 2010 to 2018. The radius of the circles in the figure is the projection of the amount of damage received by enterprises in Ukraine. The maximum size of the losses of the participants of the domestic economic system was recorded in 2014, at the same time, by the quantity indicator of the number of loss-making enterprises, the leader was 2010. By the end of 2018, more than a quarter of all business entities operating in domestic markets for goods and services and forming the basis of the Ukrainian economy are unprofitable. Such sad statistics are evidence of the negligent attitude of the management of enterprises, institutions, organizations to the task of ensuring their financial and economic security. The realities of doing business in Ukraine in an unstable economic environment make adjustments to the list of priority interests of the business structures. Attempts to maximize profits in post-crisis conditions of economic activity should be changed to maintain a level of 
profitability that allows them to remain in the market without losing financial stability and competitiveness in the strategic perspective due to the impact on the results of economic activities of various types of internal and external threats. This circumstance should be reflected in the strategies of management of financial and economic security of economic entities.

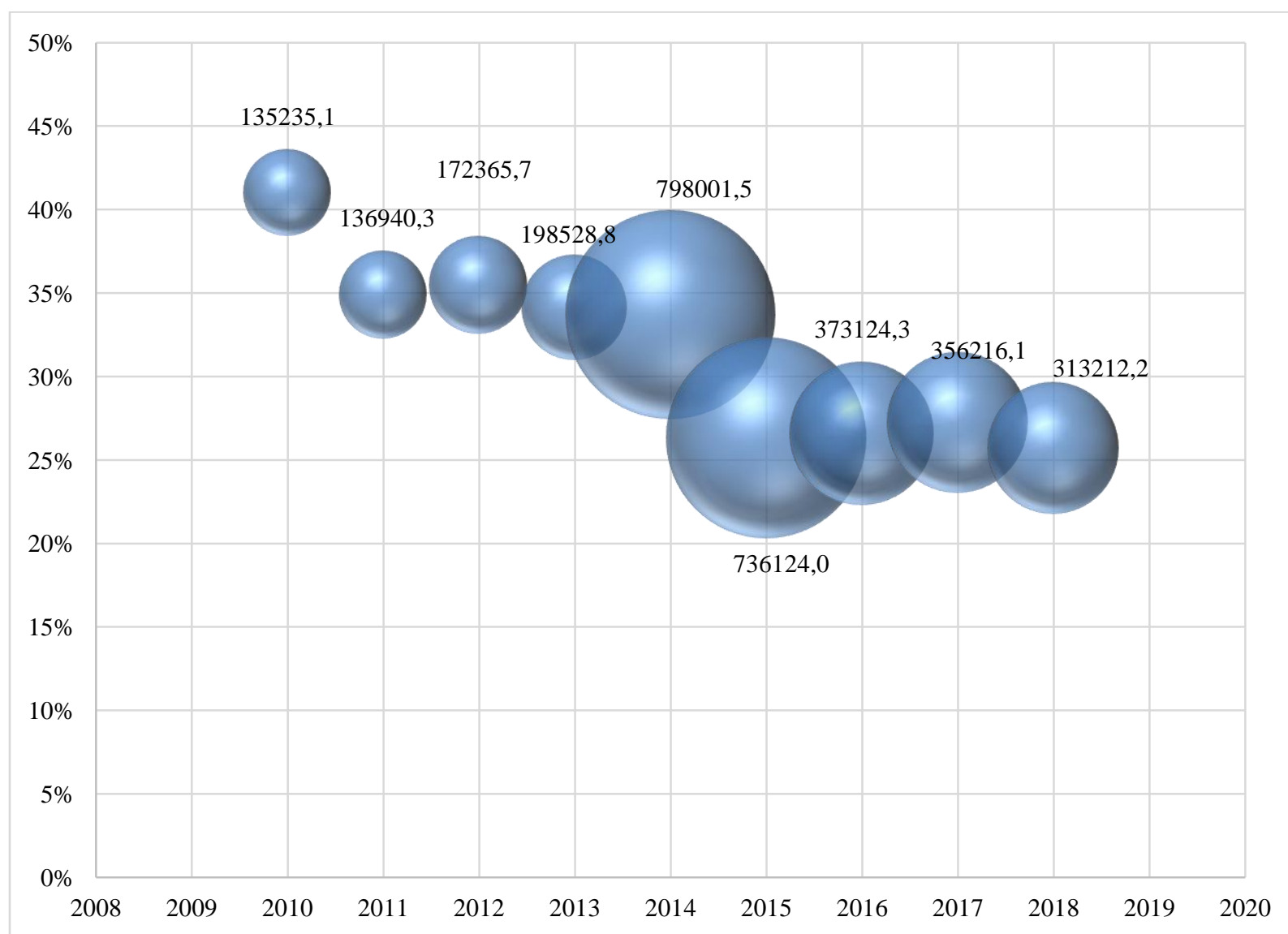

Fig. 2. Number of unprofitable business entities and their financial result, UAH million Source: [18], own research.

Domestic researchers of problems of security science, O.V. Makarchuk, Yu.Yu. Pechora believe that "the strategy of economic security is a formed set of measures that are adequate to the state and trends of changes in the external and internal environment, which, in accordance with available resources, ensures stable functioning and necessary tendencies development in accordance with the chosen mission "[13, p.136]. "Strategic management of economic security of the enterprise," in their opinion, "must first of all obey the main goal and the key tasks of the enterprise's economic strategy, to foresee possible changes of the environment in order to implement a number of adaptive measures to prevent the occurrence of risks and threats that would increase the level of danger, rely on available resources and promote the use of additional opportunities that may arise in the internal environment "[13, p.137-138]. Thus, the process of preparation for the implementation of strategic management of financial and economic security has the following stages (Fig. 3).

According to Stolyarenko O.O., "strategic management of economic security is a process of managing strategic planning and an elaborated strategy of economic security, taking into account the interconnection of the internal environment of the enterprise with the external and adaptation to their changes in order to achieve the goal of the enterprise and protect it from the impact of threats, risks and the achievement of normal and safe functioning "[14, c.322]. The process of implementation of strategic management of financial and economic security is proposed to be carried out in nine stages: to identify the mission and objectives of the enterprise, to monitor the external environment, to identify threats to economic security, to conduct an analysis of the internal environment, to carry out a strategic analysis of the level of economic security, to organize the 
formation of strategic alternatives, elect the strategy of economic security, conduct evaluation and management of the implementation of the strategy and carry out strategic control and correction of the strategy [13, c.324].

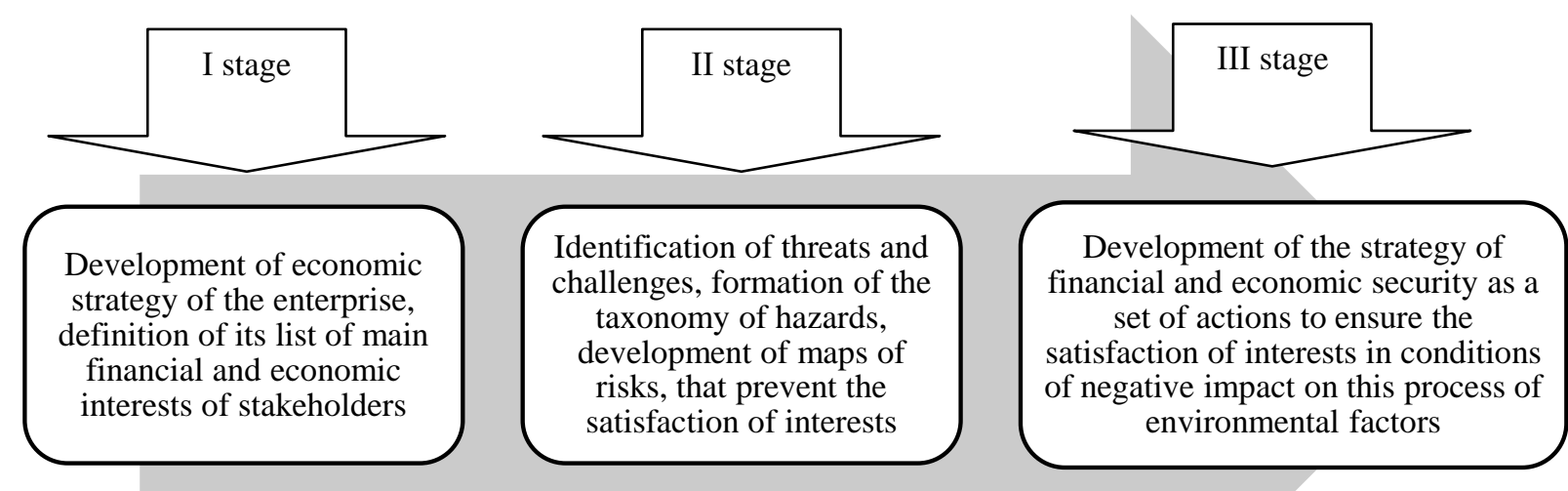

\section{Fig.3. A phased approach to the introduction of strategic management of financial and economic security at enterprises}

Source: own research.

The author's approach is as follows. Under the strategic management of economic security, the enterprise is encouraged to understand a set of consistent long-term measures initiated and conducted on the basis of management decisions, the implementation of which will enable the company to operate in the conditions of the maximum possible level of protection of its resources and resources of related individuals, which will create conditions for achieving its purpose creation and satisfaction of interests of its stakeholders. Implementation of strategic management of financial and economic security should be carried out in such sequences (Fig. 4).

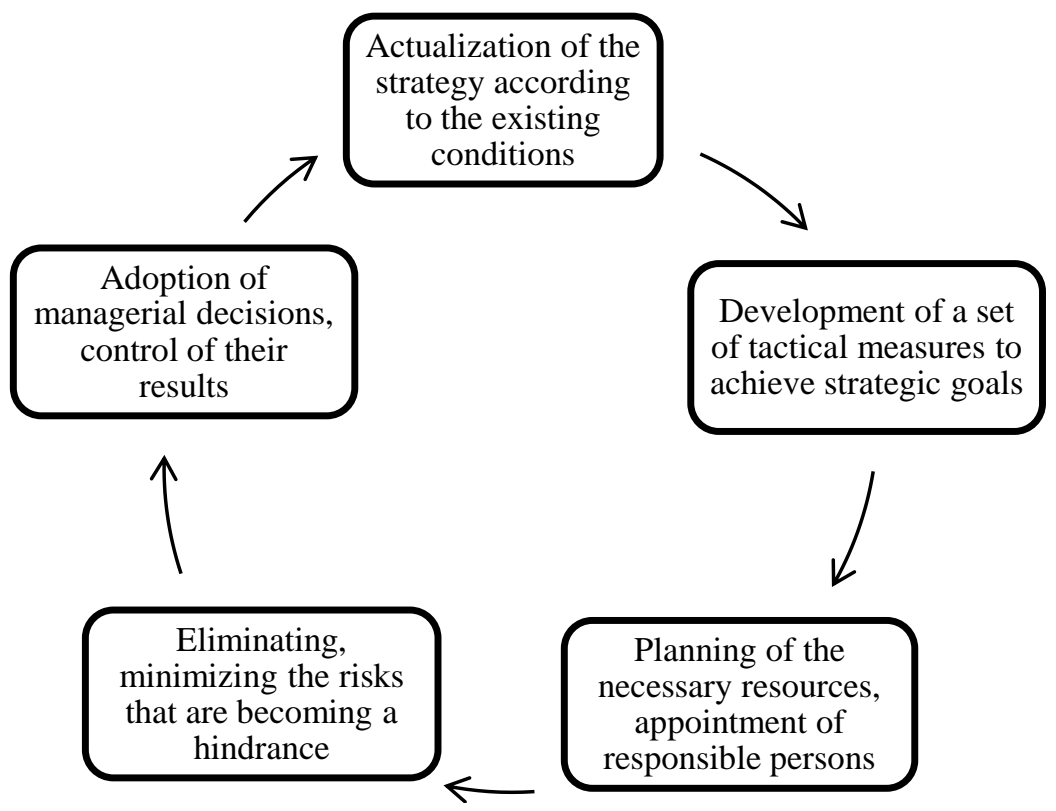

Fig.4. Stages of strategic management of financial and economic security of economic entities

Source: own research.

Consequently, an important aspect of strategic management of financial and economic security of economic entities is the awareness of the target orientations of such management. The National Bank of Ukraine is constantly conducting a survey to determine the business expectations 
of domestic enterprises. It is expedient to set the basis for a set of strategic guidelines in the process of realizing economic activity as a whole, as well as in choosing vectors for implementing measures to manage financial and economic security of economic structures (Table 1).

Table 1

Business expectations of Ukrainian enterprises as strategic benchmarks for managing financial and economic security

\begin{tabular}{|c|c|}
\hline As of Q1 2019 & $\begin{array}{c}\text { Security-oriented management solutions in the } \\
\text { strategic perspective }\end{array}$ \\
\hline Growth of production volumes & $\begin{array}{c}\text { Avoiding overcosts, checking partners and counterparties, } \\
\text { quality control of products }\end{array}$ \\
\hline Increase the level of business activity & Checking new partners and clients \\
\hline Reducing inflation & $\begin{array}{l}\text { View pricing policies } \\
\end{array}$ \\
\hline Devaluation of the national currency & Formation of currency basket of financial resources \\
\hline Reduce the need for borrowed funds & $\begin{array}{c}\text { Estimation of opportunities for effective allocation of own } \\
\text { capital }\end{array}$ \\
\hline Increase in energy prices & Formation of reserves to compensate for additional costs \\
\hline Insufficient level of own entrepreneurial capacities & $\begin{array}{c}\text { Updating and upgrading equipment, using leasing } \\
\text { opportunities }\end{array}$ \\
\hline $\begin{array}{l}\text { Failure to satisfy demand in the event of an increase in } \\
\text { its level }\end{array}$ & Increase in inventory to ensure continuity of production \\
\hline Increase in the number of employees & $\begin{array}{l}\text { Strengthening the level of personnel security (personnel } \\
\text { loyalty control, staff assessment at recruitment, detailed } \\
\text { study of recommendations) }\end{array}$ \\
\hline Increase in investment volume & $\begin{array}{l}\text { Risk assessment of investment projects, assessment of the } \\
\text { cost of capital from various sources }\end{array}$ \\
\hline
\end{tabular}

Source: [19], own research.

At the same time as attempts to establish business expectations for domestic business representatives, the National Bank of Ukraine experts annually establish a set of key risks and challenges that hinder the development of professional participants in the financial sector, but are relevant to the rest of the business structures, and therefore should be taken into account by the companies top management under time to develop their strategies for financial and economic security. As of the beginning of 2019, the list of such risks included:

- corruption, law enforcement and judicial system;

- political and social situation in Ukraine;

- the state of cooperation with international financial organizations;

- state of protection of the rights of creditors and investors;

- fraud and cybernetic threats;

- dynamics of world prices for commodities;

- access to funding;

- war with Russia (military actions in eastern Ukraine);

- dynamics of inflow of foreign capital (including direct investments) into Ukraine;

- quality of legislation and tax system;

- quality of human capital;

- dynamics and volatility of the exchange rate;

- asset value and collateral quality;

- state economic policy (monetary, fiscal, etc.);

- market competition;

- the possibility of bankruptcy and / or significant financial difficulties;

- level of economic activity;

- current and expected inflation;

- level and dynamics of real estate prices [20]

Existing risks and challenges in the economic system lead to the need to adjust the interests of different categories of stakeholders. Thus, military actions in the East make companies manage to find safe markets for their products, diversify their partnerships and transform logistics systems. 
Convergence with the EU countries and the volatility of the exchange rate increases the level of interest in the euro as the equivalent of the US dollar currency for mediating settlements during the implementation of foreign economic relations between economic entities. The challenges posed by the digital economy have created the need to develop on-line services, to expand the capabilities of electronic services, which naturally led to the emergence of cyber threats and the steady demand for the protection of information resources, while expanding the boundaries of information transparency. The phenomenon of corruption, which is firmly rooted in the practices of the organization of Ukrainian business, requires the management of enterprises additional costs of financial, time and human resources to fight for their rights and interests.

Thus, awareness of existing and potential challenges and threats to the state of financial and economic security, specifying the interests of different categories of stakeholders and their balance should be reflected in the strategies of financial and economic security of economic entities - the conceptual documents for management of financial and economic security of business structures.

Conclusions. The study of the theoretical foundations of strategic management of financial and economic security at the present stage of the development of security science made it possible to make the following important conclusions.

1. Under the strategic management of economic security of enterprise should be understood a set of consistent long-term measures initiated and conducted on the basis of management decisions, the implementation of which will enable the enterprise to operate in the conditions of the maximum possible level of protection of its resources and resources of related parties, which will create the conditions for achievement. the purpose of its creation and the satisfaction of the interests of its stakeholders.

2. The statistics of the number of economic entities in Ukraine and the number of unprofitable business entities in ten years show a tendency to deteriorate the analyzed indicators, which may be due to the lack of a strategic management of their financial and economic security in the top management of business structures. In view of this, a step-by-step approach to the introduction of strategic management of financial and economic security at enterprises was proposed. At the first stage, it is proposed to develop the economic strategy of the enterprise, to identify in it a list of the main financial and economic interests of stakeholders. At the second stage, there should be: identification of threats and challenges, formation of taxonomy of hazards, development of maps of risks, that hinder the satisfaction of the interests of the enterprise and those who interested in its results of activities. The third stage proposes the development of a strategy of financial and economic security as a set of actions to ensure satisfaction of the interests of the company and its stakeholders in the conditions of negative impact on this process of environmental factors.

3. The stages of strategic management of financial and economic security of economic entities are presented in the form of a closed management cycle. The first stage involves updating the strategy in accordance with the existing conditions, the second is the development of a set of tactical measures for achieving strategic goals, the third is the planning of the necessary resources, the appointment of responsible persons, the fourth - the elimination, minimization of risks that impede the security-oriented management, the fifth - making managerial decisions, controlling their outcome. In line with the business expectations of Ukrainian enterprises, which were determined by the experts of the National Bank of Ukraine in the end and quarter of 2019 as a result of business representatives' surveys, a set of strategic benchmarks for managing the financial and economic security of domestic business entities in the long term was formed.

Prospects for further research are seen in the development of a universal, basic strategy of financial and economic security as a conceptual document of strategic security-oriented management at the level of economic entities. 
1. Furman, V.M., Zachosova, N.V. (2015) Features of the management of economic security of modern insurance companies as one of the types of financial institutions. Zhurnal «Ahrosvit» (Journal «Agrosvit»), 15, 20-26 (in Ukr).

2. Zachosova, N.V. (2018) Theoretical and methodological principles of management of economic security in the process of management of modern financial institutions. Visnyk Odeskoho natsionalnoho universytetu. Seriya : Ekonomika (Bulletin of the Odessa National University. Series: Economics), 2, 11-20 (in Ukr).

3. Zachosova, N.V. (2019) Modeling of the mechanism for managing the provision of financial and economic security for professional participants in the financial market, taking into account the state influence on this process. Naukovi zapysky Natsionalnoho universytetu "Ostrozka akademiya» seriya "Ekonomika» (Scientific notes of the National University "Ostroh Academy» series «Economics»), 12 (40), 101-105. DOI: 10.25264/2311-5149-201912(40)-101-105 (in Ukr).

4. Zanora, V.O., Sklyar, A.V. (2016) Management of economic safety of subjects of management: theoretical and methodical aspects of organization of the system. Naukovyy visnyk Mizhnarodnoho humanitarnoho universytetu. Seriya : Ekonomika i menedzhment (Scientific Bulletin of the International Humanitarian University. Series: Economics and Management), 22, 74-77 (in Ukr).

5. Zanora, V. O., Silchenko, B. I. (2017) Management of the enterprise's economic security system based on the project approach. Ekonomichnyy visnyk Zaporizkoyi derzhavnoyi inzhenernoyi akademiyi (Economic Bulletin of the Zaporizhzhya State Engineering Academy), 5(1), 130-133 (in Ukr).

6. Tulub, O. M., Teslyuk, O. M. (2016). Management of the system of financial and economic safety of the manufacturing firm. Investytsiyi: praktyka ta dosvid (Investments: practice and experience), 16, 29-32 (in Ukr).

7. Zachosova, N.V. (2016) Definition of strategic guidelines for strengthening the economic security of financial institutions as a necessary stage in the formation of the economic security strategy of Ukraine. Biznes Inform (Business Inform), 1, 272-276 (in Ukr).

8. Cherevko, O. V. (2014) Strategic management of financial and economic security of the enterprise. Efektyvna ekonomika (Effective economy), 2014, 2. Retrieved from: http://nbuv.gov.ua/UJRN/efek_2014_2_83 (in Ukr).

9. Dotsenko, I. O. Melnychuk, O. P. (2018) Strategic management of financial and economic security of the enterprise. Derzhava ta rehiony. Seriya : Ekonomika ta pidpryyemnytstvo (State and regions. Series: Economics and Business), 3, 79-84 (in Ukr).

10. Shabinskyy, O. V. (2014) Problems of development of the strategy of economic security management of agricultural sector enterprises. Visnyk Kharkivskoho natsionalnoho ahrarnoho universytetu im. V. V. Dokuchayeva. Ser.: Ekonomichni nauky (Bulletin of Kharkiv National Agrarian University named after V. V. Dokuchaev: Economics), 5, 201-206 (in Ukr).

11. Levytskyy, V. V. Sukhanova, I. Yu. (2014) Innovative development as an element of strategic provision of the system of financial and economic security management of the enterprise. Naukovyy visnyk [Bukovynskoho derzhavnoho finansovo-ekonomichnoho universytetu]. Ekonomichni nauky (Scientific Bulletin [Bukovinsky State Financial-Economic University]. Economic Sciences), 26, 89-94 (in Ukr).

12. Sudakova, O. I., Popova, V. V., Orlova, M. K. (2014) Improvement of strategic management of economic safety of the enterprise. Ekonomichnyy prostir (Economical space), 88, 239-246 (in Ukr).

13. Makarchuk, O. V. Pechora, Yu. Yu. (2014) Strategic management of enterprise economic safety: theoretical aspects. Naukovi zapysky [Ukrayinskoyi akademiyi drukarstva] (Scientific notes [Ukrainian Academy of Printing]), 4, 135-139 (in Ukr).

14. Stolyarenko, O. O. (2012) The analysis of stages of the process of strategic management of economic safety of the enterprise. Naukovyy visnyk NLTU Ukrayiny (Scientific Bulletin of NLTU of Ukraine), 22.8, 320-325 (in Ukr).

15. Bril, M. S. (2015) Methodology of Strategic Alternatives for Managing the Economic Security of a Commercial Bank. Biznes Inform (Business Inform), 2, 196-203 (in Ukr).

16. Kyrychenko, O. (2016) Theoretical Foundations of Strategic Management of the System of Economic Security of the Enterprise. Naukovyy visnyk [Odeskoho natsionalnoho ekonomichnoho universytetu] (Scientific Bulletin [Odessa National Economic University]), 1, 70-83 (in Ukr).

17. Ustenko, S. V., Ivanchenko, N. O. (2014) Development of an imperative strategy for managing the economic security of an enterprise. Naukovyy visnyk Khersonskoho derzhavnoho universytetu. Ekonomichni nauky (Scientific Bulletin of Kherson State University. Economics), 8(1), 213-217 (in Ukr).

18. Materials of the official site of the State Statistics Service of Ukraine. Retrieved from: http://www.ukrstat.gov.ua (cited: 3 March 2019).

19. Business Expectations of Ukrainian Enterprises. 1st quarter of 2019. Retrieved from: https://bank.gov.ua/doccatalog/document?id=92021349 (cited: 3 March 2019).

20. Survey on Systemic Risks of the Financial Sector. Retrieved from: https://bank.gov.ua/doccatalog/document?id=95852313 (cited: 3 March 2019). 
аспірант (PhD Доктор філософіï)

кафедри менеджменту та економічної безпеки,

Черкаський національний університет

імені Богдана Хмельницького, м. Черкаси, Україна

lawagens@gmail.com

\title{
ОРІЄНТИРИ СТРАТЕГІЧНОГО УПРАВЛІННЯ ФІНАНСОВО-ЕКОНОМІЧНОЮ БЕЗПЕКОЮ ПІДПРИЕМСТВ: ІНТЕРЕСИ, ВИКЛИКИ, РИЗИКИ
}

\begin{abstract}
Анотація
Актуальність. Особливого значення нині набуває питання стратегічного управління фінансовоекономічною безпекою. Це зумовлено тим, що підприємства, установи та організації, що звикли боротися за свою конкурентоспроможність, рентабельність та економічне виживання на сповненому загроз внутрішньому ринку, однак, боротьба ия має форму спонтанної, миттєвої реакиії на небезпеку, яку вдалося виявити засобами аналізу та моніторингу стану ринкового середовища або внутрішнього клімату бізнесструктури. Таким чином, станом на середину 2019 року менеджмент фінансово-економічної безпеки - ие не що інше, як окремі, оперативні реакиії на дію загроз і тактичні дії щодо подолання наслідків їх негативного впливу на ресурси та інтереси суб'єкта господарювання. Однак, результативність управлінського процесу можна суттєво підвищити шляхом планування безпеко орієнтованих заходів, прогнозування загроз і ризиків стану фінансово-економічної безпеки підприємств.

Мета статті полягає у конкретизації директив стратегічного управління фінансово-економічною безпекою підприємств, які визначаються на основі фінансово-економічних інтересів суб'єктів господарської діяльності та їх стейкхолдерів, викликів, що постають перед підприємством у зовнішньому та внутрішньому середовищах у процесі їх реалізації, а також ризиків для стану їх фінансово-економічної безпеки.

Методи. У процесі дослідження використані монографічний метод і метод теоретичного аналізу. Також застосовано прийоми аналізу і синтезу. Метод узагальнення використано у процесі формування висновків за результатами проведеного дослідження.

Результати. У статті запропоновано авторську дерініцію стратегічного управління фінансовоекономічною безпекою. Конкретизовано особливості формування стратегій забезпечення фінансовоекономічної безпеки господарських структур. Визначено перелік основних викликів і ризиків для фінансовоекономічної безпеки вітчизняних підприємств. Запропоновано авторський підхід до організації прочесу запровадження стратегічного управління фінансово-економічною безпекою на підприємствах. Встановлено стратегічні орієнтири для управління фінансово-економічною безпекою відповідно до ділових очікувань підприємств України.
\end{abstract}

Новизна. Запропоновано поетапний підхід до запровадження стратегічного управління фінансовоекономічною безпекою на підприємствах. На першому етапі пропонується здійснити розробку економічної стратегії підприсмства, визначити у ній перелік основних фінансово-економічних інтересів стейкхолдерів. На другому етапі мають проводитись: ідентифікаиія загроз $і$ викликів, формування таксономії небезпек, розробка карт ризиків, що стають на заваді задоволенню інтересів підприємства $і$ зацікавлених у його результатах діяльності осіб. На третьому етапі пропонується розробка стратегії фінансово-економічноі безпеки як сукупності дій щодо забезпечення задоволення інтересів підприємства і його стейхолдерів у умовах негативної дї̈ на цей прочес факторів середовища. Визначено стадії стратегічного управління фінансовоекономічною безпекою суб'єктів господарювання, що представлено у формі замкнутого управлінського ииклу. Перша стадія передбачає актуалізацію стратегії відповідно до наявних умов, друга - розробку набору тактичних заходів для досягнення стратегічних иілей, третя - планування необхідних ресурсів, призначення відповідальних осіб, четверта - усунення, мінімізацію ризиків, що стають на заваді безпеко орієнтованому управлінню, п'ята - прийняття управлінських рішень, контроль їх результату.

Висновки. Під стратегічним управлінням економічною безпекою підприємства належить розуміти сукупність послідовних довгострокових заходів, що ініціюються та проводяться на основі управлінських рімень, реалізаиія яких дозволить підприємству функиіонувати в умовах максимально можливого рівня захисту його ресурсів, і ресурсів пов'язаних осіб, що створить умови для досягнення мети його створення та задоволення інтересів його стейкхолдерів. Дані статистики кількості суб'єктів господарської діяльності 6 Україні та кількості збиткових суб'єктів господарювання за десять років демонструють тендениію до погіршення аналізованих показників, що може бути наслідком відсутності у вищого керівництва підприємницьких структур візї стратегічного управління їх фінансово-економічною безпекою. Тому перспективи подальших досліджень вбачаються у розробиі універсальної, базової стратегії фінансовоекономічної безпеки, як концептуального документу стратегічного безпеко орієнтованого управління на рівні суб'єктів господарської діяльності.

Ключові слова: управління, фінансово-економічна безпека, стратегічне управління, загрози, інтереси, виклики, ризики. 